\title{
PENYULUHAN PENATALAKSANAAN ALERGI YANG MEMBERIKAN KELUHAN KULIT GATAL PADA LANSIA DI PANTI WERDHA SALAM SEJAHTERA
}

\author{
Fia Fia $^{1}$, Johan $^{2}$, Chrismerry Song ${ }^{3}$, Christian Wijaya ${ }^{4}$ \\ ${ }^{1}$ Fakultas Kedokteran Universitas Tarumanagara, Jakarta \\ Email: fiaf@fk.untar.ac.id \\ ${ }^{2}$ Fakultas Kedokteran Universitas Tarumanagara, Jakarta \\ Email: johan@fk.untar.ac.id \\ 3Fakultas Kedokteran Universitas Tarumanagara, Jakarta \\ Email: chrismerrys@fk.untar.ac.id \\ ${ }^{4}$ Fakultas Kedokteran Universitas Tarumanagara, Jakarta \\ Email: christianw@fk.untar.ac.id
}

\begin{abstract}
ABSTRAK
Alergi adalah suatu reaksi hipersensitivitas yang diperantarai oleh mekanisme imunologi, yang dapat memengaruhi hampir seluruh jaringan tubuh dan menimbulkan gejala klinik sesuai dengan organ yang terkena. Prevalensi penyakit alergi pada lansia diperkirakan sekitar 5-10\%. Penyakit alergi ini akan mengganggu, menurunkan kualitas dan produktivitas hidup penyandangnya. Beberapa penyakit alergi yang sering pada lansia adalah penyakit alergi saluran nafas seperti rhinitis alergika, asma bronkiale, dermatitis, alergi obat, dan urtikaria dan angioedema. Penyakit alergi yang difokuskan pada penyuluhan ini adalah kelainan kulit yang dapat memberikan keluhan berupa gatal-gatal. Beberapa alergen di sekitar tempat tinggal yang sudah terbukti dapat mencetuskan alergi antara lain tungau debu rumah, kecoa, jamur, atau serpihan kulit binatang peliharaan. Beberapa penghuni panti menderita gatal-gatal pada kulit, namun usaha pencegahan dan penanganan terhadap keluhan tersebut belum maksimal. Berdasarkan kondisi tersebut, maka dosen dan mahasiswa FK Untar mengadakan penyuluhan untuk meningkatkan pengetahuan lansia tentang penatalaksanaan alergi yang memberikan keluhan kulit gatal pada lansia di panti werdha Salam Sejahtera. Penyuluhan ini ditujukan meningkatkan tingkat pengetahuan dan kesehatan lansia sehingga dapat mengetahui upaya terbaik terhadap keuhan, sehingga diharapkan kualitas hidup lansia dapat meningkat. Penyuluhan ini diikuti oleh penghuni, care giver dan pengurus panti dengan seksama dan antusias.
\end{abstract}

Kata kunci: Alergi, Lansia, Kulit Gatal, Penatalaksanaan

\section{PENDAHULUAN}

Alergi adalah suatu reaksi hipersensitivitas yang diperantarai oleh mekanisme imunologi, yaitu reaksi atau respon tubuh yang berlebihan terhadap alergen (Portnoy, 2015). Alergi dapat timbul pertama kali pada usia anak-anak, dewasa muda, atau pada lansia (lanjut usia). Reaksi alergi dapat memengaruhi hampir seluruh jaringan tubuh dan menimbulkan gejala klinik sesuai dengan organ yang terkena. Menurut data dari World Allergy Organization prevalensi alergi penduduk dunia berkisar antara $10-40 \%$ (Pawankar, 2011). Kelompok usia yang rentan terhadap alergi adalah kelompok lansia. Prevalensi penyakit alergi pada lansia diperkirakan sekitar 5-10\% (Cardona, 2011). Meningkatnya status sosial dan ekonomi menyebabkan meningkatkan angka harapan hidup di Indonesia. Pusdatin Kemenkes RI memperkirakan kecenderungan peningkatan lansia cukup pesat di Indonesia dibandingkan kelompok usia lainnya sejak tahun $2013(8,9 \%)$ hingga tahun 2050 (21,4\%) (Kemenkes RI, 2016). Berdasarkan peningkatan jumlah tersebut, maka jumlah penyakit yang berhubungan dengan lanjut usia, termasuk alergi, diperkirakan akan meningkat.

Faktor resiko yang menyebabkan lansia lebih mudah terkena alergi antara lain adalah kerapuhan (frailty), adanya penyakit lain yang menyertai, gangguan memori dan konsumsi obat-obatan. Perubahan ketahanan tubuh berupa immunosenesence (penuaan sistem imun) pada lansia berpengaruh pada sistem imun bawaan dan adaptifnya, sehingga lansia lebih rentan terhadap penyakit autoimun, keganasan, dan juga infeksi. Selain itu respon tubuh lansia terhadap vaksinasi 
dan penyembuhan luka juga akan terpengaruh (Martinis, 2017). Selain itu, terjadinya penurunan fungsi sistem kekebalan tubuh pada lansia juga menyebabkan respon sel-sel tubuh terhadap alergen dapat berubah. Umumnya penyakit alergi kurang terdiagnosis karena lansia lebih terfokus pada penyakit lain seperti jantung, paru-paru, dan lainnya. Seringkali gejala alergi juga tertutup oleh gejala akibat penyakit-penyakit tersebut.

Beberapa penyakit alergi yang sering pada lansia adalah rhinitis alergika, asma bronkiale, dermatitis, alergi obat, dan urtikaria dan angioedema (Portnoy, 2015). Penyuluhan yang dilakukan difokuskan kepada penyakit alergi yang dapat memeberikan keluhan gatal, yaitu: dermatitis, alergi obat, dan urtikaria dan angioedema. Penyakit dermatitis pada lansia memberi gambaran perubahan penuaan kulit yang ditandai dengan atrofi lapisan dermis dan epidermis karena hilangnya hidrasi kulit karena proses penuaan sel dan faktor lingkungan. Perubahan fungsi dan struktur kulit ini menyebabkan rusaknya fungsi barrier (pelindung) kulit, rusaknya pembuluh darah, terjadi ketidakseimbangan reaksi metabolik di kulit dan berubahnya komponen matriks ekstraseluler (Martinis, 2017).

Alergi obat sebagai akibat dari Adverse drug reaction (ADR) lebih sering ditemukan pada lansia yang rapuh. ADR didapatkan 2-3 kali lebih sering pada lansia dibandingkan dengan dewasa muda dan diperkirakan bertanggungjawab terhadap $10 \%$ dari kejadian perawatan RS pada lansia (karena overdosing). Urtikaria adalah kelainan kulit yang terbatas pada bagian superfisial, berupa bentol berbatas tegas yang dikelilingi oleh daerah yang kemerahan. Pada bagian tengah bentol didapatkan warna yang lebih pucat. Biasanya kelainan ini bersifat sementara, gatal, dan dapat terjadi di seluruh tubuh. Angioedema adalah pembengkakan lokal dengan batas lebih tegas yang melibatkan lapisan kulit yang lebih dalam bila dibandingkan urtikaria (Martinis, 2017).

Patogenesis terjadinya penyakit alergi secara garis besar dibagi menjadi 2 jalur, yaitu jalur imunologis dan jalur non-imunologis. Pada jalur imunologis, setelah allergen (zat pemicu alergi) masuk ke dalam tubuh, alergen akan diolah oleh antigen presenting cell (APC), dan akan ditangkap oleh sel T helper. Setelah sel T teraktivasi oleh APC, sel T akan memberikan instruksi melalui interleukin atau sitokin agar sel plasma membentuk IgE, sel radang lain seperti mastosit, makrofag, eosinophil, neutrophil, trombosit, serta limfosit untuk mengeluarkan mediator inflamasi. Mediator inflamasi seperti histamin, prostaglandin, leukotrien, bradikinin, tromboksan dan lain-lain akan mempengaruhi organ sasaran sehingga menyebabkan pelebaran pembuluh darah, peningkatan permeabilitas pembuluh darah, edema saluran nafas, infiltrasi sel radang dan lain-lain. Pada jalur non-imunologis, terjadi perangsangan sistem saraf otonom yang dengan hasil akhir berupa inflamasi (Ventura, 2017).

Beberapa zat di sekitar tempat tinggal yang sudah terbukti dapat mencetuskan alergi antara lain tungau debu rumah, kecoa, jamur, atau serpihan kulit binatang peliharaan. Selain itu alergi juga dapat disebabkan oleh makanan dan obat-obatan yang dikonsumsi. Tungau debu rumah adalah serangga mikroskopik mirip laba-laba, yang diketahui merupakan salah satu alergen tersering yang menimbulkan masalah pada kulit berupa dermatitis atopik (Calderon, 2015). Antigen dari tubuh tungau debu rumah masuk ke dalam tubuh manusia melalui penetrasi kulit, sedangkan antigen dari partikel tinjanya dapat masuk ke dalam tubuh manusia melalui inhalasi (terhirup) (Mantu, 2016).

Upaya terbaik terhadap penyakit alergi pada lansia adalah tindakan pencegahan, mamun pada beberapa situasi penyebab alergi tidak dapat dihindarkan secara total, terutama alergen yang ada di udara (aerogen) dan debu (tungau debu rumah). Pada keadaan dimana alergi telah terjadi, penanganan alergi pada lansia membutuhkan perhatian khusus, karena medikamentosa yang 
dipakai untuk mengatasi alergi pada umumnya mempunyai efek berbeda pada lansia. Selain itu, terjadi peningkatan insidens terjadinya alergi obat pada lansia, sebanyak 2-3 kali lebih banyak dibanding dewasa muda (Cardona, 2011). Pada lansia interaksi obat juga lebih sering terjadi karena pemakaian obat yang banyak (polifarmasi). Untuk itu, diperlukan pemahaman yang tepat mengenai tatalaksana alergi pada lansia.

Tatalaksana alergi pada lansia dapat berupa pemberian obat (farmakoterapi) dan nonfarmakoterapi. Tatalaksana farmakoterapi antara lain antihistamin, kortikosteroid, imunoterapi dan obat-obat simptomatik sesuai dengan gejala khas alergi yang terjadi. Pemberian antihistamin generasi pertama harus dihindarkan pada lansia karena obat-obat ini dapat melewati sawar darahotak dan menyebabkan efek samping pada susunan saraf pusat. Efek samping yang ditimbulkan dapat berupa kebingungan, mengantuk, kepala terasa melayang, gangguan fungsi kognitif, gangguan berkemih, konstipasi, agangguan irama jantung, vasodilatasi pembuluh darah perifer, hipotensi ortostatik/postural, takikardi (denyut jantung cepat). Efek-efek di atas dapat menyebabkan jatuh, perburukkan hipertrofi prostat, glaukoma dan penyakit jantung. Jika dibutuhkan, maka yang dapat diberikan adalah antihistamin generasi kedua yang tidak menyebabkan efek samping ke susunan saraf pusat. Namun yang harus diperhatikan adalah obatobat ini dimetabolisme di hati, sehingga dapat berinteraksi dengan obat lain, dan harus disesuaikan pada lansia yang fungsi hatinya menurun. Obat golongan ini juga gangguan ginjal karena diekskresi melalui ginjal (Cardona, 2011).

Efek samping kortikosteroid dapat lebih buruk pada lansia dibanding dewasa muda, antara lain gangguan daya ingat, diabetes melitus, katarak, osteoporosis, ulkus peptik (jika dikombinasi dengan obat anti inflamasi non steroid), dan lain-lain. Kortikosteroid topikal dapat diberikan pada lansia untuk mengurangi terjadinya efek samping sistemik, namun harus diberikan dengan hatihati karena efek samping seperti penipisan kulit, atrofi kulit, pelebaran pembuluh darah kulit dan gangguan aksis hipotalamus-hipofise tetap dapat terjadi akibat penyerapan dari kulit (Cardona, 2011; Cohen, 2012).

Tatalaksana non farmakoterapi dapat berupa tindakan pencegahan dan tindakan untuk mengurangi keluhan (Cohen, 2012; Polat, 2015). Pencegahan dermatitis dapat dilakukan antara lain dengan menghindari mandi berlebihan dengan air hangat dengan sabun yang bersifat alkaline dan mengandung alkohol. Untuk mengurangi kekeringan pada kulit dan menjaga fungsi pertahanan kulit, dapat dilakukan dengan pemakaian pelembab (disarankan pelembab dengan $\mathrm{pH}$ rendah, sesuai kondisi alami kulit) setelah mandi dan emolien yang mengandung urea 5\% atau $10 \%$ (Cohen, 2012). Selain itu, untuk mengatasi gatal, yang harus diperhatikan adalah tidak menggaruk daerah yang terkena, karena garukan dapat menyebabkan luka, iritasi dan menyebabkan pelepasan mediator yang memperburuk rasa gatal. Pakaian yang dipakai tidak boleh terlalu ketat dan tidak mengiritasi kulit. Suhu yang nyaman dengan kelembapan optimal $(<40 \%)$ juga harus dijaga untuk mencegah penguapan dan keluar keringat yang terlalu banyak. Sediaan yang mengandung menthol $1 \%$ juga dapat diberikan untuk memberikan sensasi dingin dan mengurangi rasa gatal.

Panti werdha Salam Sejahtera berada di kawasan Kecamatan Bogor Utara, Kota Bogor, Jawa Barat, dan dihuni oleh lansia di atas 60 tahun. Panti ini telah menjalin kerjasama dengan FK Universitas Tarumanagara sejak Oktober 2017 dan digunakan sebagai salah satu tempat pelaksanaan kegiatan kepaniteraan geriatri. Panti ini memiliki 136 kamar, yang dihuni sekitar 85 sampai 90 orang, berikut caregiver. Dari hasil visitasi berkala yang dilakukan selama kepaniteraan geriatri, didapatkan beberapa penghuni memiliki keluhan gatal-gatal. 
Pada kegiatan PKM ini, tim FK Untar yang terdiri dari dosen dan mahasiswa, mengadakan penyuluhan untuk meningkatkan pengetahuan lansia tentang penatalaksanaan penyakit alergi, terutama yang memberikan keluhan kulit gatal pada lansia. Upaya ini diharapkan dapat meningkatkan tingkat pengetahuan dan kesehatan lansia sehingga dapat mengetahui pencegahan kulit gatal. Lansia yang memiliki keluhan gatal juga dapat mengetahui tatalaksana yang paling tepat untuk penyakitnya, sehingga diharapkan kualitas hidup lansia dapat meningkat.

\section{METODE PELAKSANAAN KEGIATAN}

Kegiatan pengabdian masyarakat ini dilaksanakan dengan melakukan kegiatan penyuluhan bagi para petugas, penanggung jawab, dan lansia penghuni Panti Werdha Salam Sejahtera. Kegiatan penyuluhan dilakukan oleh 1 orang dokter spesialis farmakologi dan dimoderatori oleh seorang dokter. Penyuluhan tersebut mengambil tema tentang pencegahan dan cara menangani penyakit alergi pada lansia, terutama untuk masalah pada kulit. Penyuluhan tersebut membahas mengenai obat anti alergi yang tidak boleh dikonsumsi lansia karena dapat menyebabkan efek samping yang merugikan. Penyuluhan diberikan dalam bentuk presentasi dengan lebih banyak gambar daripada kalimat. Bentuk penyajian ini dimaksudkan agar mudah dimengerti oleg peserta penyuluhan.

\section{HASIL PELAKSANAAN KEGIATAN}

Kegiatan penyuluhan diselenggarakan pada hari Sabtu, 11 Mei 2019 jam 09.00 - 12.00 di gedung serbaguna Panti Werdha Salam Sejahtera, Jalan Raya Pajajaran No. 38B, Bantarjati, Bogor Utara, Bantarjati, Kec. Bogor Utara, Kota Bogor, Jawa Barat 16153. Acara ini diikuti oleh 68 lansia penghuni panti, caregiver dan pengurus panti.

Acara dimulai dengan pembukaan dan menyanyikan lagu bersama untuk memberi semangat lansia yang hadir. Kata sambutan diberikan oleh perwakilan dari FK Untar oleh DR. dr. Noer Saelan Tadjudin, Sp.KJ dan penanggung jawab panti werdha Salam Sejahtera dr. Johan Gautama.

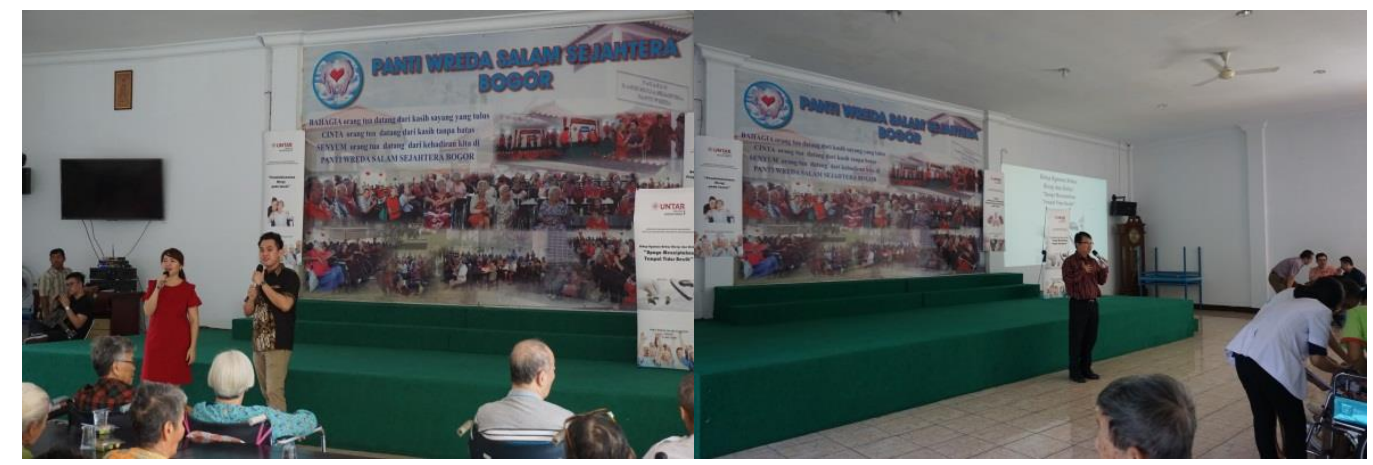

Gambar 1: Pembukaan acara dan kata sambutan oleh DR. dr. Noer Saelan Tadjudin, Sp.KJ

Acara kemudian dilanjutkan dengan presentasi oleh narasumber dan tanya jawab yang dipandu oleh moderator. Kesempatan ini digunakan dengan baik oleh lansia untuk bertanya tentang masalah pada kulitnya. Setelah acara tanya jawab selesai, tim mengadakan acara kebersamaan berupa bernyanyi lagu-lagu melodi memori bersama-sama, serta meminta beberapa lansia untuk maju ke depan berpartisipasi dalam bernyanyi. Acara kebersamaan ini diikuti dengan antusias, dan beberapa lansia ikut bernyanyi menyumbang lagu untuk dinyanyikan bersama. 


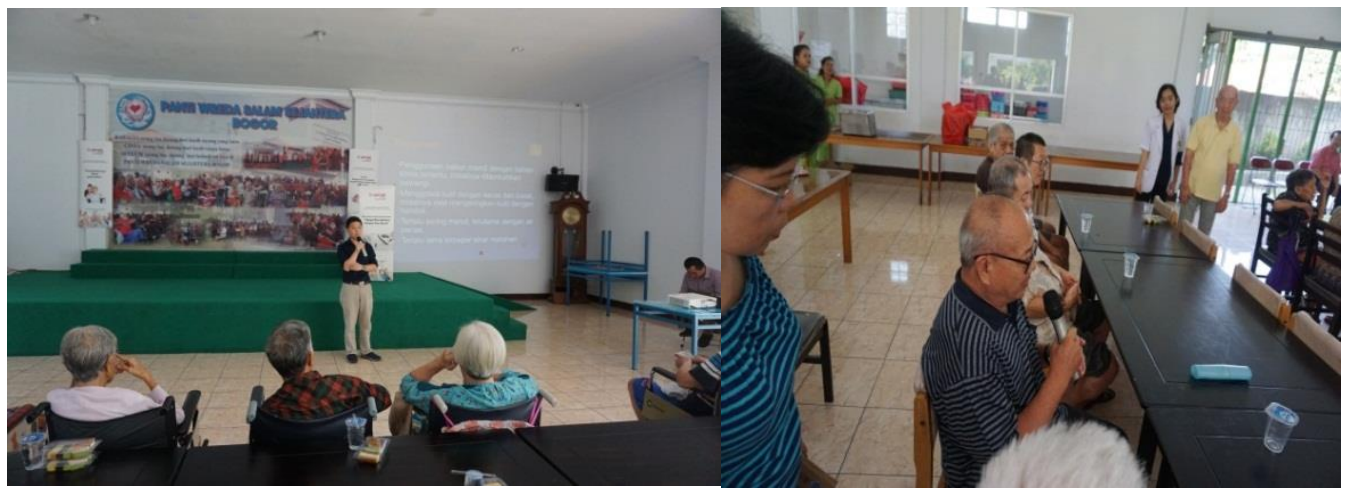

Gambar 2: Presentasi oleh narasumber dan peserta lansia bertanya.

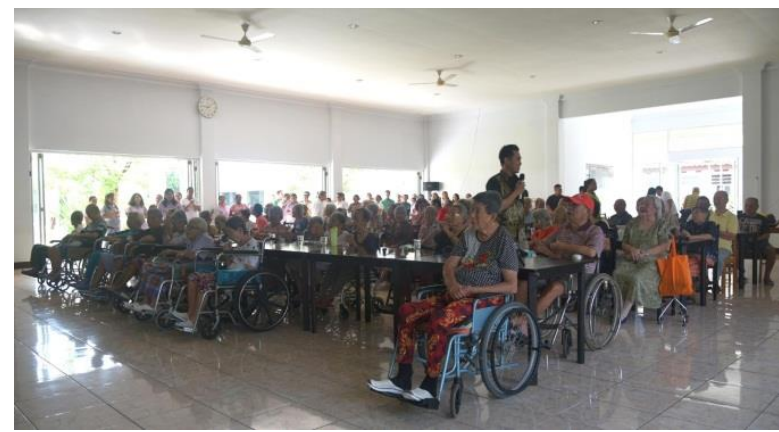

Gambar 3: Peserta yang ikut acara terdiri dari lansia, caregiver dan pengurus panti

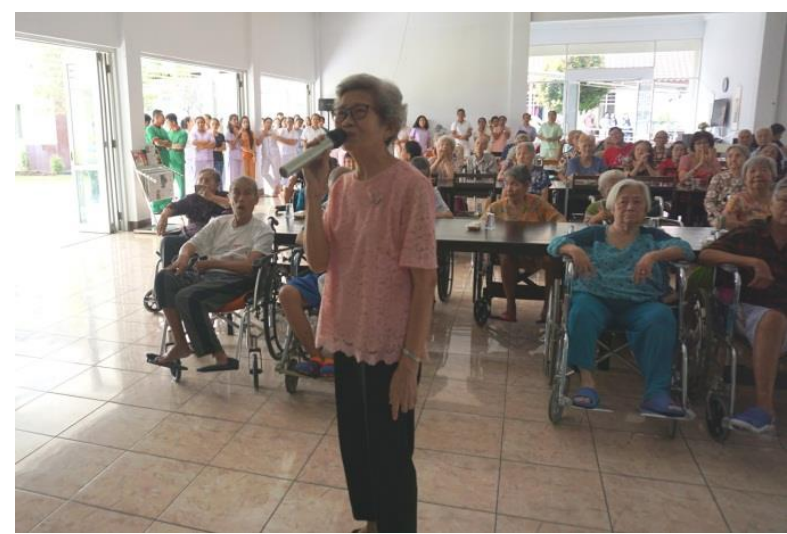

Gambar 4: Acara Kebersamaan bernyanyi lagu-lagu melody memory

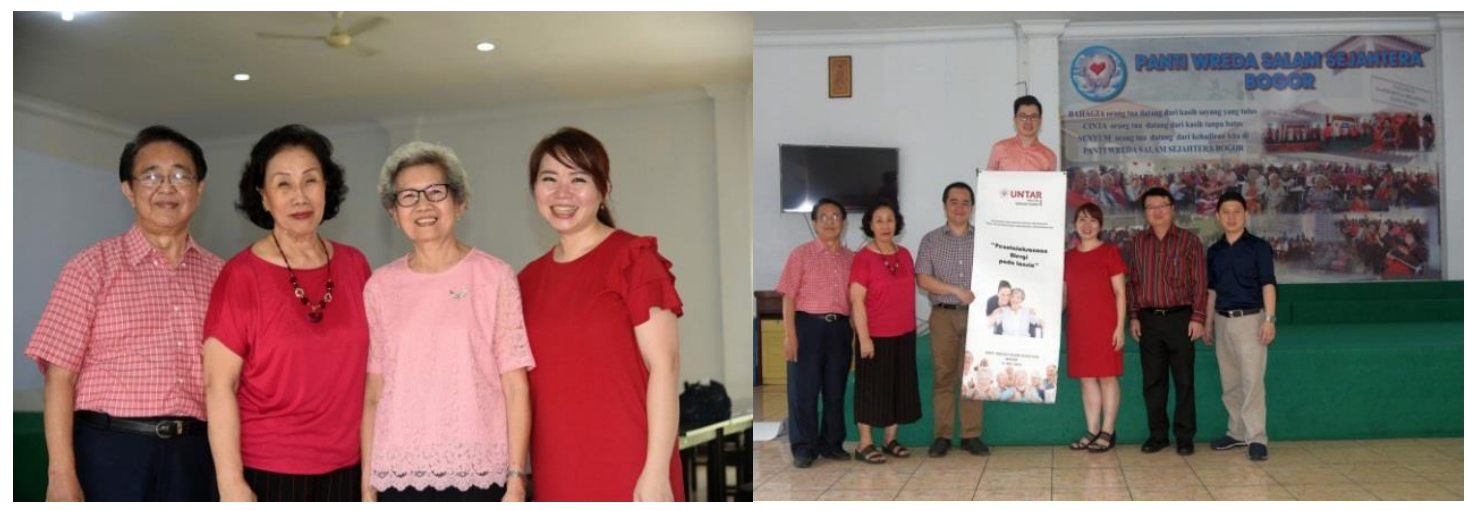

Gambar 5: Foto bersama oma Shinta penghuni panti (kiri) dan panitia yang ikut serta (kanan) 


\section{KESIMPULAN DAN SARAN}

Upaya untuk meningkatkan tingkat kesehatan dan kualitas hidup lansia di Panti Werdha Salam Sejahtera dilaksanakan dalam bentuk penyuluhan mengenai penatalaksanaan (pencegahan dan penanganan) penyakit alergi, terutama pada kulit, kepada petugas, penanggung jawab, dan penghuni panti. Diharapkan lansia dapat terbebas dari penyakit alergi,pada kulit dan dapat mengetahui tatalaksana yang paling tepat untuk penyakitnya. Lansia juga mengetahui obat-obatan antialergi yang harus dihindari, karena dapat menyebabkan efek samping yang merugikan.

Setelah dilaksanakan, didapatkan respon yang baik dari kegiatan ini baik, sehingga kegiatan serupa juga dapat dilakukan di mitra panti-panti lain yang juga merupakan tempat kepaniteraan klinik geriatri mahasiwa/i FK Untar. Kegiatan PKM dilakukan secara rutin untuk mengatasi masalah kesehatan lain yang dimiliki oleh lansia yang ada di panti Salam Sejahtera, maupun panti werdha lain yang merupakan mitra Fakultas Kedokteran Universitas Tarumangara. Kegiatan tersebut di masa mendatang dapat dilakukan dengan menjalin kerjasama dengan berbagai disiplin ilmu baik di Fakultas Kedokteran.

\section{Ucapan Terima Kasih (Acknowledgement)}

Ucapan terima kasih disampaikan kepada pengelola Panti Werdha Salam Sejahtera, atas perkenannya untuk dilaksanakana kegiatan ini. Juga terimakasih kepada para peserta peenyuluhan yang mengikuti dengan penuh semangat. serta pihak-pihak yang terlibat dalam kegiatan PKM ini.

\section{DAFTAR PUSTAKA}

Calderon et al. (2015). "Respiratory allergy caused by house dust mites: What do we really know?" J Allergy Clin Immunol, volume 136 (1): 38-48

Cardona V, Guilarte M, Luengo O, Labrador-Horrilo M, Salla-Cunil A, Garriga T.(2011). "Allergic Diseases in Eldery" Clinical and Translational Allergy, vol 1:11.

Cohen KR, Frank J, Salbu RL, et al. (2012) "Pruritus in the Elderly: Clinical Approaches to the Improvement of Quality of Life" P\&T.;37:4.

Kemenkes RI, Pusat data dan informasi (2016) "Situasi dan analisis lanjut usia" Available from: www.pusdatin.kemkes.go.id/resources/download/pusdatin/infodatin/infodatinlansia.pdf

Mantu BG, Wahongan GJ, Bernadus JB. (2016) "Hubungan kepadatan tungau debu rumah dengan derajat rinitis alergi" Jurnal e-Biomedik. 4. 10.35790/ebm.4.1.2016.11056.

Martinis M, Sirufo M M, Ginaldi L.(2017) :Allergy and Aging: an Old/New Emerging Health Issue" Aging and Disease, 8;2;162-175.

Pawankar R, Holgate ST, Canonica GW, Lockey RF. (2011). WAO White Book on Allergy. World Allergy Organization, Milwaukee, Wiscounsin.

Polat M, Ilhan MN. (2015) "Dermatological Complaints of the Elderly Attending a Dermatology Outpatient Clinic in Turkey: A Prospective Study over a One-year Period". Acta Dermatovenerol Croat, vol 23(4):277-281

Portnoy J. (2015). "IgE in Clinical Allergy and Allergy Diagnosis" World Allergy Organization [cited 1 February 2019]. Available from: https://www.worldallergy.org/education-and-programs/education/allergic-diseaseresource-center/professionals/ige-in-clinical-allergy-and-allergy-diagnosis

Ventura M, Schchilone N, Paganelli R, Mincuilo P, Patella V, Bonini M, et al. (2017) “Allergic disease in eldery: biological characteristics and main immunological and nonimmunological mechanisms" Clin Mol Allergy, vol 5:2. 